\title{
Improved Indonesian Language Learning Outcomes using Problem Based Learning Methods for Class III SD Students
}

\section{Bangkit Subarkah}

SD Negeri Surorejo

Bankqt10@gmail.com

\section{Article History}

accepted 01/11/2020

approved 08/11/2020

published 15/11/2020

\begin{abstract}
The purpose of this study was to improve student learning outcomes in Indonesian muples by using the problem based learning method. This research is a Classroom Action Research (PTK) using two cycles. Each cycle consists of planning, implementing, observing and reflecting. In this study using post tests. In the first cycle, $81 \%$ students completed while in the second cycle it was $100 \%$. These results indicate that the Problem Based Learning method can improve the learning outcomes of Indonesian students in grade III SD Negeri Surorejo.
\end{abstract}

Keywords: research, problem based learning, Indonesian Language

\section{Abstrak}

Tujuan penelitian ini adalah untuk meningkatkan hasil belajar peserta didik pada mupel Bahasa Indonesia dengan menggunakan metode problem based learning. Penelitian ini merupakan Penelitian Tindakan Kelas (PTK) dengan menggunakan dua siklus. Setiap siklus terdiri dari perencanaan, pelaksanaan, pengamatan dan refleksi. Pada penelitian ini menggunakan post tes. Pada siklus I peserta didik yang tuntas sebanyak $81 \%$ sedangkan pada siklus II sebanyak $100 \%$. Hasil ini menunjukkan bahwa metode Problem Based Learning dapat meningkatkan hasil belajar Bahasa Indonesia siswa kelas III SD Negeri Surorejo.

Kata kunci: Penelitian, Problem Based Learning, Bahasa Indonesia

Social, Humanities, and Education Studies (SHEs): Conference Series https://jurnal.uns.ac.id/shes 


\section{PENDAHULUAN}

Pendidikan Indonesia adalah seluruh pendidikan yang diselenggarakan di Indonesia, baik itu secara terstruktur maupun tidak terstruktur. Secara terstruktur, pendidikan di Indonesia menjadi tanggung jawab Kementerian Pendidikan dan Kebudayaan Republik Indonesia (Kemdikbud), dahulu bernama Departemen Pendidikan Nasional Republik Indonesia (Depdiknas). Di Indonesia, semua penduduk wajib mengikuti program wajib belajar pendidikan dasar selama sembilan tahun, enam tahun di sekolah dasar/madrasah ibtidaiyah dan tiga tahun di sekolah menengah pertama/madrasah tsanawiyah. Saat ini, pendidikan di Indonesia diatur melalui Undang-Undang Nomor 20 Tahun 2003 tentang Sistem Pendidikan Nasional.

Salah satu jenjang pendidikan adalah Sekolah dasar (SD). Masa usia Sekolah Dasar merupakan periode emas (golden age) bagi perkembangan anak untuk memperoleh proses pendidikan. Periode ini adalah tahun-tahun berharga bagi seorang anak untuk mengenali berbagai macam fakta di lingkungannya sebagai stimulans terhadap perkembangan aspek kepribadian, kognitif, psikososial, maupun moralnya.

Untuk itu pendidikan anak untuk usia Sekolah Dasar dalam bentuk pemberian rangsangan-rangsangan (stimulasi) dari lingkungan terdekat sangat diperlukan untuk mengoptimalkan kemampuan anak.Pembentukan kemampuan siswa di sekolah dipengaruhi oleh proses belajar yang ditempuhnya. Proses belajar akan terbentuk berdasarkan pandangan dan pemahaman guru tentang karakteristik siswa dan juga hakikat pembelajaran.

Proses pembelajaran pada kurikulum 2013 diawali kegiatan mengamati oleh siswa dengan cara melihat, membaca, mendengar dan menyimak tentang masalah yang berkaiatan dengan materi pelajaran. Setelah siswa mengamati, siswa dapat bertanya tentang apa yang dilihat, dibaca, didengar dan disimak baik secara lisan maupun tulisan. Langkah selanjutnya kegiatan menganalisis dengan cara mengumpulkan informasi, menghubungkan informasi yang didapat oleh siswa, dan menentukan keterkaitan antara informasi yang satu dengan lainnya (mengolah informasi). Kegiatan akhir yang dilakukan oleh siswa adalah mengomunikasikan hasil pengamatan yang telah dibuat oleh siswa. Dalam kurikulum 2013 pembelajaran berbasis tematik.

Peneliti memilih SD Negeri Surorejo karena dalam pemebelajaran Bahasa Indonesia siswa kelas 3 hanya menitik beratkan penguasaan konsep saja. Guru masih menggunakan metode konvensional secara monoton dalam kegiatan pembelajaran di kelas, sehingga suasana belajar terkesan kaku dan didominasi oleh guru. Guru menyampaikan materi dengan metode ceramah, dimana siswa hanya duduk, mencatat, dan mendengarkan apa yang disampaikannya, sehingga ketika siswa diminta untuk bertanya oleh guru banyak yang tidak melakukannya. Hal ini karena siswa kurang termotivasi untuk lebih aktif mengutarakan pendapat, ide, gagasan, pertanyaan dan kesulitan-kesulitan maupun hal-hal yang belum dipahami selama pelajaran. Suasana pembelajaran menjadi tidak kondusif, sehingga hasil belajar masih rendah.

Untuk meningkatkan hasil belajar siswa salah satunya adalah penggunaan metode. Metode problem base learning merupakan salah satu metode pembelajaran yang sesuai dengan abad 21. Dimana dapat nenumbuhkan anak untuk perpikir kritis dan kreatif. Oleh sebab itu, penulis melakukan penelitian tindakan kelas yang berjudul "Upaya Meningkatkan Hasil Belajar Bahasa Indonesia Menggunakan Metode Problem Based Learning Pada Siswa Kelas III SD Negeri Surorejo".

Dari masalah yang ada penulis dapat merumuskan masalah sebagai berikut: bagaimana peningkatan hasil belajar Bahasa Indonesia siswa kelas III SD Negeri Surorejo? Dengan tujuan penelitian mendiskripsikan peningkatan hasil belajar Bahasa Indonesia menggunakan metode problem based learning . 
Menurut Sudjana (2010: 22), hasil belajar adalah kemampuan yang dimiliki siswa setelah menerima pengalaman belajar. Selanjutnya Warsito (dalam Depdiknas, 2006: 125) mengemukakan bahwa hasil dari kegiatan belajar ditandai dengan adanya perubahan perilaku ke arah positif yang relatif permanen pada diri orang yang belajar. Sehubungan dengan pendapat itu, maka Wahidmurni, dkk. (2010: 18) menjelaskan bahwa sesorang dapat dikatakan telah berhasil dalam belajar jika ia mampu menunjukkan adanya perubahan dalam dirinya.

Finkle and Torp (1995) dalam Aris Shoimin (2014:130) menyatakan bahwa: PBM merupakan pengembangan kurikulum dan sistem pengajaran yang mengembangkan secara stimulan strategi pemecahan masalah dan dasardasar pengetahuan dan keterampilan dengan menempatkan para peserta didik dalam peran aktif sebagai pemecah permasalahan sehari-hari yang tidak terstruktur dengan baik. Sedangkan menurut Kamdi (2007:77) berpendapat bahwa: Model Problem Based Learning diartikan sebagai sebuah model pembelajaran yang didalamnya melibatkan siswa untuk berusaha memecahkan masalah dengan melalui beberapa tahap metode ilmiah sehingga siswa diharapkan mampu mempelajari pengetahuan yang berkaitan dengan masalah tersebut dan sekaligus siswa diharapkan akan memilki keterampilan dalam memecahkan masalah.

\section{METODE}

Jenis penelitian ini adalah peneliatian tindakan kelas (Classroom Action Reseach) dengan menerapkan metode Problem Based Learning. Penlian ini terdiri dari empat taham dalam setiap siklusnya yang meliputi perencanaan, pengamatan dan refleksi. Teknik analisis data yang digunakan yaitu deskptif kuantitatif dan kualitatif. Subjek penelitian ini adalah siswa kelas III SD Negeri Surorejo semester I tahun pelajaran 2020/2021. Siklus I dilaksanakan kamis 22 Oktober 2020 sedangkan siklus II dilaksanakan pada Senin 2 November 2020. Teknik pengumpulan data delakukan dengan observasi dan tes. Observasi digunakan untuk melihat keterlaksanaan metode problem based learning serta sikap peserta didik. Sedangkan tes digunakan untuk melihat hasil belajar Bahasa Indonesia menggunakan metode problem based learning.

\section{HASIL DAN PEMBAHASAN}

Siklus I diakan pada hari Senin 2 November 2020 dengan materi bahasa Indonesia yaitu kalimat saran. Di sini peneliti melakukan pembelajaran menggunakan langkah-langkah metode problem base learning yang terdiri dari langkah sebagai berikut: orientasi peserta didik terhadap masalah, mengorganisasi siswa, membimbing penyelidikan, mengembangkan/ menyajikan hasil, menganalisis dan evalusi masalah. Berikut adalah hasil belajar peserta didik pada siklus I yang dapat dilihat pada tabel belikut

Tabel 1. Hasil belajar siklus I

\begin{tabular}{llc}
\hline No & \multicolumn{1}{c}{ Uraian } & Jumlah siswa \\
\hline 1 & Rata-rata & 80 \\
2 & Nilai tertinggi & 100 \\
3 & Nilai Terendah & 40 \\
4 & Siswa tuntas & 13 \\
5 & Siswa belum tuntas & 3 \\
4 & Prosentase ketuntasan & $81 \%$ \\
5 & Prosentase belum tuntas & $19 \%$ \\
\hline
\end{tabular}


Dari tabel di atas dapat diuraikan bahwa pada siklus I rata- rata kelas 80 , nilai tertinggi 100 , nilai terendah 40 , siswa tuntas 13 , siswa belum tuntas 3 , prosentase ketuntasan $81 \%$, dan prosentase belum tuntas $19 \%$.

Setelah melakukan refleksi pada siklus I maka diputuskaan untuk melanjutkan pada siklus II karena belum mencapai target yang dicapai. Pada siklus II ini diharapkan terjadi peningkatan hasil belajar siswa terutama pada mupel Bahasa Indonesia. Pada siklus II ini materi masih sama yaitu mengenai kalimat saran karena pada siklus II melanjutkan pembelajaran yang lalu. Pembelajaran pada siklus II masih menggunakan metode problem based learning dengan langkah langkah pembelajaran sebagai berikut: orientasi peserta didik terhadap masalah, mengorganisasi siswa, membimbing penyelidikan, mengembangkan/ menyajikan hasil, menganalisis dan evalusi masalah. Hasil pembelajaran Bahasa Indonesia menggunakan metode problem based learning dapat dilihat pada tabel berikut ini.

Tabel 1. Hasil belajar siklus I

\begin{tabular}{llc}
\hline No & \multicolumn{1}{c}{ Uraian } & Jumlah siswa \\
\hline 1 & Rata-rata & 92 \\
2 & Nilai tertinggi & 100 \\
3 & Nilai Terendah & 80 \\
4 & Siswa tuntas & 16 \\
5 & Siswa belum tuntas & 0 \\
4 & Prosentase ketuntasan & $100 \%$ \\
5 & Prosentase belum tuntas & $0 \%$
\end{tabular}

Dari tabel di atas dapat diuraikan sebagai berikut bahwa pada sikus II rata-rata kelas adalah 92, nilai tertinggi 100 , nilai terendah 80 , siswa tuntas 16 , siswa belum tuntas 0 , prosentase ketuntasan $100 \%$, prosentase belum tuntas $0 \%$. Pada taham refleksi peneliti membuat keputusan untuk menghentikan penelitian ini karena telah mencapai target.

Berikut ini akan dideskripsikan hasil nilai rata-rata siswa tiap-tiap siklus I dan siklus II. Pada siklus I rata-rata kelas 80 dan pada siklus II meningkat lagi menjadi 92. Sedangkan di aspek siswa yang memenuhi KKM atau yang tuntas pada siklus I terdapat 13 siswa atau $81 \%$ dan pada siklus II meningkat lagi yaitu 16 siswa atau $100 \%$. Untuk lebih jelasnya dapat dilihat pada gambar di bawah ini.

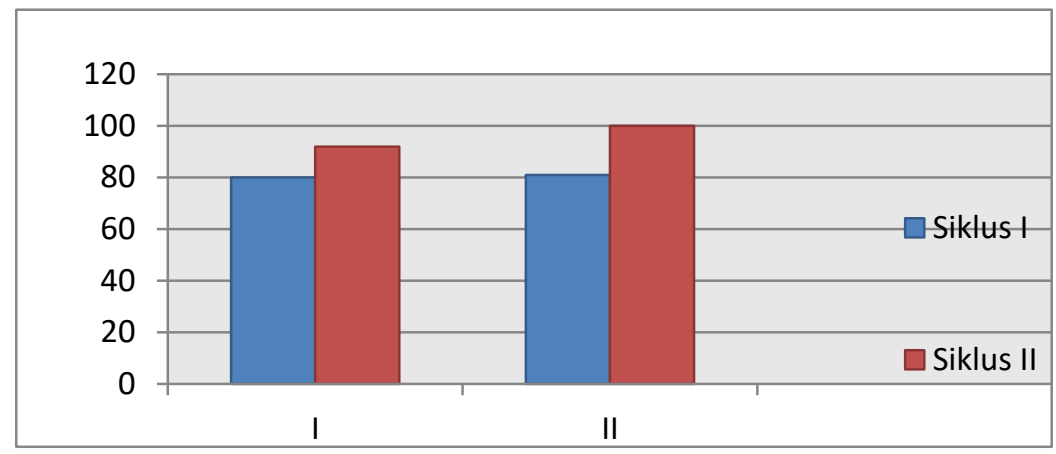

Gambar 1. Peningkatan hasil belajar Bahasa Indonesia

Keterangan:

I : Perbandingan nilai rata-rata tes tertulis.

II : Perbandingan nilai yang memenuhi KKM (Tuntas) 
Dari 2 siklus yang telah dilaksanakan dapat dipastikan bahwa metode problem based learning dapat meningkatkan hasil belajar Bahsa Indonesia siswa kelas III SD Negeri Surorejo. Hal ini sesuai dengan konsep yang di ungkapkan Smith dalam Amir (2009:27) bahwa dengan problem based learning siswa akan: meningkatkan kecakapan pemecahan masalahnya, lebih mudah mengingat, meningkat pemahamannya, meningkat pengetahuannya yang relevan dengan dunia praktik/kerja, mendorong mereka penuh pemikiran, membangun kemampuan kepemimpinan dan kerja sama, kecakapan belajar, dan memotivasi siswa.

\section{SIMPULAN}

Penerapan metode problem based learning dapat meningkatkan hasil belajar Bahasa Indonesia siswa kelas III SD negeri surorejo. Peningkatan yang terjadi karena pada pembelajaran dengan metode problem based learning peserta didik dituntut untuk menganalisis sendiri maslah yang ada sehingga pembelajaran lebih bermakna.

\section{DAFTAR PUSTAKA}

Amir, T. (2009). Inovasi Pendidikan Melalui Problem Based Learning. Jakarta: Kencana.

Depdiknas. (2006). Bunga Rampai Keberhasilan Guru dalam Pembelajaran (SMA, $S M K$, dan SLB). Jakarta: Depdiknas.

Kamdi, W., \& dkk. (2007). Model-Model Pembelajaran Inovatif. Malang: Universitas Negeri Malang.

Shoimin, A. (2014). 68 Model Pembelajaran Inovatif dalam Kurikulum 2013. Yogyakarta: Ar-ruzz Media.

Sudjana, N. (2010). Penilaian Hasil Proses Belajar Mengajar. (Cet. XV). Bandung: PT. Ramaja Rosdakarya.

Wahidmurni, Mustikawan, A., \& Ridho , A. (2010). Wahidmurni, Alifin Mustikawan, dan Ali Ridho Evaluasi Pembelajaran: Kompetensi dan Praktik. Yogyakarta: Nuha Letera. 